\title{
The Influence of Maturity Stage on Superoxide Dismutase and Catalase Activity in Red Guava Fruit
}

\author{
Afianti Sulastri*, A. A. Soemardji, Sukrasno Sukrasno \\ School of Pharmacy \\ Institut Teknologi Bandung \\ Bandung, Indonesia \\ *afiantisulastri@upi.edu
}

\author{
Amaliya Amaliya \\ Department of Periodonsia, Faculty of Dentistry \\ Padjadjaran University \\ Bandung, Indonesia
}

\begin{abstract}
Oxidative stress due to free radicals can cause various cell damage and its components inside, such as proteins, lipids, and DNA. Oxidative stress can be inhibited through antioxidant compounds. The liver as an essential organ plays a significant role in the metabolism process, produces endogenous antioxidant compounds that function in scavenging the free radicals through a detoxification process. In this process, besides the antioxidant which is produced by liver cells, it can also be obtained from foods intakes such as fruits and vegetables. Guava is one of the tropical plants which is known as high antioxidant resources. This study aims to determine how the ripeness of red guava impact toward its superoxide dismutase (SOD) and catalase activity. The study was conducted through experimental design on 21 male mice which divided into seven groups, i.e., one untreated group as control and six groups which are treated with vitamin $\mathrm{C}$ and various dosages of guava's fruit. Period of treatment was driven for 14 days. On the 15th day, the animals were sacrificed, and their liver organs were taken. The liver homogenate was tested for SOD and catalase activity using ELISA kit. The results showed that group which treated by medium ripe guava fruit had a better impact on catalase activity but not in SOD activity, compared with the control group.
\end{abstract}

Keywords-antioxidant; red guava; superoxide dismutase; catalase

\section{INTRODUCTION}

Oxidative stress is defined as the overproduction of reactive oxygen species that cannot be neutralized by the action of antioxidants, but also as a disruption on redox balance of cells. Reactive oxygenated/nitrogenated species are represented by superoxide radicals, hydroxyl radicals, alkoxyl and peroxyl lipids, nitric oxide and peroxinitrite. Oxidative stress due to free radicals can cause various cell damage and its components inside, such as proteins, lipids, and DNA. The imbalances between oxidant species and antioxidant defence systems can trigger some specific factors that cause oxidative damage in cells, such as: over-expression of oncogene genes, formation of mutagen compounds, increased atherogenic activity, plaque events or senile inflammation. Furthermore, these conditions can progress to cancer, neurodegeneration, cardiovascular disease, diabetes, and kidney disease [1].

Oxidative stress can be inhibited by the role of antioxidant compounds. The liver as an important organ, plays a major role in the metabolic process, produces endogenous antioxidant compounds that function in scavenging the free radicals through a detoxification process. The increases of cytochrome $\mathrm{P}-450$ oxidase enzyme activity will produce free radicals. If this occurs excessively, the body's antioxidant enzymes will unable to overcome it and the oxidative stress occur because the amount of free radicals exceeds antioxidant capacity in the body [2]. Various studies have been conducted to find alternatives anti-inflammatory agents in the new bioactive molecules form from natural products and functional foods. Fruits and vegetables are known to contain several antioxidant compounds, either singly or in association, which can affect the inflammatory process, reduce harmful effects and the risk of disease development [3].

Red guava (Psidium guajava Linn.) is one of the tropical plants which is known as high antioxidant resources. It has a sweet and aromatic fruit native to Central America and belongs to the Myrtaceae family. It has been consumed for more than 2000 years, and nowadays, it grows wild throughout the tropical and subtropical regions of the world. The popular cultivars suitable for fresh consumption are those having an intense aroma and a pink colour. During guava season, the fruit is consumed fresh or processed into juice and jam. Several countries used this plant as a traditional medicines. Many studies have demonstrated its potential as a source of bioactive compounds such as carotenoids, flavonoids and polyphenols [4]. Previous studies have shown that the extracts obtained from the leaves or fruits from guava tree (Psidium friedrichsthalianum) exhibit anti-inflammatory activity associated to the presence of phenolic compounds, by inhibition of pro-inflammatory mediators and reduction of leukocytes migration. The antioxidant activity during inflammatory reactions is important because free radicals from leukocytes, principally from neutrophils, cause some types of tissue injuries through the direct degradation of essential cellular components, or may start or amplify the inflammatory response through the modulation of the expression of many genes involved in the inflammatory process. Lycopene-rich extracts of red guava have a beneficial effect on acute inflammation, offering protection against the consequences of oxidative stress by suppressing the inflammatory mediators and inhibiting the genes expression that involved in inflammation process [3]. 
Quercetin is one of the ingredients in guava which can be used as a leading compound which has several pharmacological activities as antioxidant, antimicrobial and anti-inflammatory [5-7]. Quercetin is now largely utilized as a nutritional supplement and as a phytochemical remedy for a variety of diseases like diabetes/obesity, circulatory dysfunction, including inflammation as well as mood disorders. Owing to its basic chemical structure the most obvious feature of quercetin is its strong antioxidant activity which potentially enables it to quench free radicals from forming resonancestabilized phenoxyl radicals [5].

This study aims to determine how the ripeness of red guava influence to antioxidant effects and some partial mechanisms especially on superoxide dismutase (SOD) and catalase activity, generating information that allows biotechnological applications for the fruit and for the benefit of human health.

\section{MethodS}

\section{A. Plant Materials}

Red/pink guava (Psidium guajava) fruit were harvested (in February 2017) from Pangalengan, West Java. Each sample was taken in two stages ripeness: semi-ripe and fully-ripe. The plant was authenticated at the Herbarium Bandungense, The School of Life Science and Technology, Bandung Institute of Technology.

Fruits of two post-harvest ripening stages (BS, BT) were studied (Figure 1). BS was defined as fruit with light green colour and hard texture, and the fruit pericarp took a slightly pink tone. The external colour change at BT was associated with the appearance of light green to light yellow colour of the peel. At this stage, pericarp and pulp were completely pink.

\section{B. Other Materials}

Sodium carboxymethylcellulose, phosphate buffer saline $\mathrm{pH}$ 7.2, Sodium hydroxide, hydrochloric acid, ascorbic acid, EnzyChromTM Catalase Assay Kit (ECAT-100), and EnzyChromTM Superoxide Dismutase Assay Kit (ESOD-100).

\section{Devices}

Sonde, surgical devices, waterbath, cold temperature centrifuge (GS-15R centrifuge Beckman), $\mathrm{pH}$ meter, micropipette, incubator, centrifuge tube, regular centrifuge, vortex, flat-bottom 96 microwell-plate Elisa reader.

\section{Animals}

Male Swiss Webster mice aged 6-8 weeks with 20-30 gr of body weight from animal Laboratory of School Pharmacy, Bandung Institut of Technology. Experimental procedure was conducted according to guide for the Care and Use of Laboratory Animals, Institute for Laboratory Animal Research NRC, 1996 Washington DC: National Academic Press and accepted by animal ethics committee in School of Pharmacy, Bandung Institute of Technology.

\section{E. Preparation of Extract}

For each sample, one kilogram of fresh samples was extracted with juicer, then filtered and the filtrate was dried by freeze-drying process during 24-48 hours, depending on its water content resulting dry powder respectively.

\section{F. Superoxide Dismutase and Catalase Activities Ex Vivo Study}

Samples were diluted in $0,3 \%$ carboxymethylcellulose sodium to achieve the concentration of $8,4,100$, and $90 \mathrm{gr} / \mathrm{ml}$ for ascorbic acid, quercetin, BS, and BT solution, respectively. 21 male mice were divided into seven groups, i.e.: 1) untreated group used as a control and six experimental groups, i.e.: 1) treated with vit $\mathrm{C} 130 \mathrm{mg} / \mathrm{kg}$ bw; 2) treated with medium ripe guava fruit extract equivalent to single fruit of guava $\pm 214 \mathrm{gr}$ (BS1); 3) treated with medium ripe guava fruit extract equivalent to double fruit of guava (BS2); 4) treated with ripe guava fruit extract equivalent to single fruit of guava (BT1); 5) treated with ripe guava fruit extract equivalent to double fruit of guava (BT2); and 6) treated with quercetin $65 \mathrm{mg} / \mathrm{kg}$ bw. The treatment was driven for 14 days. On the 15th day, the animals were sacrificed and their liver organs were taken. 500 mg male rat liver are homogenized in $250 \mu 1$ cold PBS pH 7.2 then centrifuge $4,000 \mathrm{rpm}$ at $4^{\circ} \mathrm{C}$ for $10 \mathrm{~min}$ to pellet any debris. Its supernatant used for SOD and catalase activities assay.

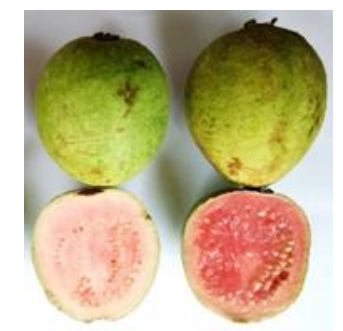

Fig. 1. Red guava fruits in two different ripening stages.

\section{RESULTS}

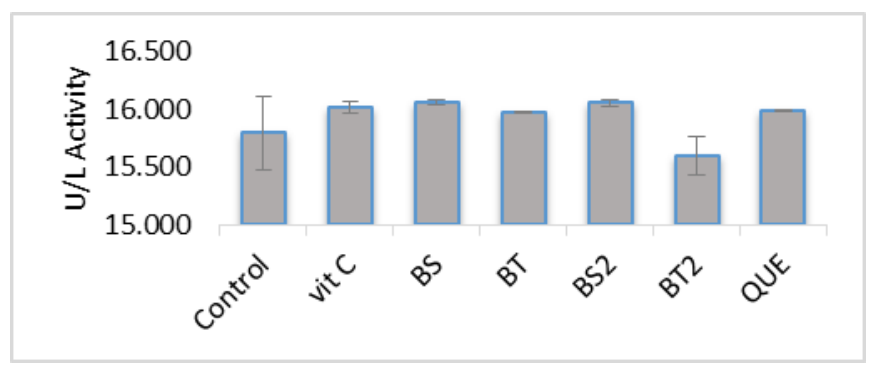

Fig. 2. Catalase activity after two weeks period of treatments. 
TABLE I. DATA OF CATALASE AND SOD ACTIVITy POST-TREATMENT WITH VARIOUS DOSAGE

\begin{tabular}{|c|l|l|l|l|l|l|}
\hline $\begin{array}{c}\text { Control } \\
\text { group }\end{array}$ & $\begin{array}{c}\text { Exp. } \\
\text { group }\end{array}$ & $\begin{array}{c}\text { Dosage } \\
(\mathbf{g} / \mathbf{k g} \\
\text { bw) }\end{array}$ & $\begin{array}{c}\text { Catalase } \\
\text { activity } \\
(\mathbf{U} / \mathbf{L})\end{array}$ & Sig. & $\begin{array}{c}\text { SOD } \\
\text { activity } \\
(\mathbf{U} / \mathbf{L})\end{array}$ & Sig. \\
\hline $\begin{array}{l}\text { Untreated } \\
\text { group }\end{array}$ & Vit c & 0.13 & $\begin{array}{l}16.025 \pm \\
0.048\end{array}$ & .059 & $\begin{array}{l}0.587 \pm \\
0.120\end{array}$ & .121 \\
\cline { 2 - 7 } & BS1 & 1.2 & $\begin{array}{l}16.068 \pm \\
0.022\end{array}$ & .028 & $\begin{array}{l}0.231 \pm \\
0.000\end{array}$ & .205 \\
\cline { 2 - 7 } & BT1 & 1.04 & $\begin{array}{l}15.974 \pm \\
0.008\end{array}$ & .132 & $\begin{array}{l}0.300 \pm \\
0.521\end{array}$ & .205 \\
\cline { 2 - 7 } & BS2 & 2.4 & $\begin{array}{l}16.060 \pm \\
0.025\end{array}$ & .032 & $\begin{array}{l}0.300 \pm \\
0.183\end{array}$ & .834 \\
\cline { 2 - 7 } & BT2 & 2.08 & $\begin{array}{l}15.605 \pm \\
0.166\end{array}$ & .106 & $\begin{array}{l}0.541 \pm \\
0.195\end{array}$ & .004 \\
& & & $15.990 \pm$ & .104 & $-0.165 \pm$ & .000 \\
\cline { 2 - 7 } & QUE & 0.065 & 0.008 & & 0.295 & \\
\hline
\end{tabular}

The results showed that all treatment groups gave catalase enzyme activity compared to control. There were statistically difference on group treated using medium-ripe guava fruit, either using a single dose or double as showed in Figure 2. They have the highest catalase activity among treatment groups. The results of measurement of SOD activity (Figure 3) showed that only groups which given vitamin $\mathrm{C}$ and both of BS dosage, single dose and double, they showed SOD activity. However, statistically there were no significant difference in SOD activity in the four treatment groups compared to control $(\mathrm{p}<0,05)$. Meanwhile, in the group given quercetin (Que) and double doses of ripe guava fruit (BT2) because there wasn't show any SOD activity, indicated by negative in scavenging activity.

\section{DISCUSSION}

The antioxidant compounds play an important role during an inflammatory reaction in scavenging free radicals from leukocytes, especially those from neutrophils, which may cause manifestations in forming tissue injury through direct degradation of several essential cell components, or strengthening the inflammatory response through modulating expression of several genes which involved in the inflammatory process [3]. The dosage guava fruit extract was calculated by converting human dose $( \pm 214 \mathrm{gr} /$ day or equivalent to one piece of guava fruit daily). Group treated with medium ripe guava give highest antioxidant activity especially in affecting both of catalase enzyme and SOD activities. This can happen because one of its ingredient such as flavonoids in the fruit is higher than that of ripe fruit, thus contributing significantly toward its antioxidant activity. The results showed several of dosage guava fruit extract did not provide a significant difference statistically. This fact is in line with Sukandar who noted that in the further ripening phase, different content of phenolic acid in fruits will condense and form some complex phenolic compounds such as tannins and lignin's. The presence of this phenolic compounds affects the antioxidant activity. This study also emphasize that use of quercetin itself can be better in extract form compared to its use as a single compound as seen on Fig.2. Other studies implied that the flavonoid in guava is dominated by quercetin compounds. It has also been found that the quercetin content in guava is mostly tied inbounding with its aglycons and slightly in free form. Metwally has succeeded to isolate five flavonoid compounds, namely: quercetin, quercetin-3-O- $\alpha-\mathrm{L}-$ arabinofuranoside, quercetin-3-O- $\beta$-D-arabinopyranoside, quercetin-3-O- $\beta$-D-glucoside, and quercetin- $3-O-\beta-D-$ galactoside in which those five compounds show good antimicrobial activities [5-7]. Both DPPH radical scavenging and metal chelating activities of the medicinal plants were dependent on the amount of phenols and flavonoids in the extract [4]. During the maturation process, the SOD activity increases but then decreases again when the fruit passes through. Some studies report a decrease in SOD (an enzyme that produces $\mathrm{H}_{2} \mathrm{O}_{2}$ ) during senescence of various plant systems may promote $\mathrm{O}_{2}$ radical accumulation and oxidative stress. Indeed, as a climacteric fruit, guava may possibly to increase in generating free oxygen radicals which followed by subsequent developments. Decreasing SOD on the overripe stage that implicates to $\mathrm{O}_{2}$ accumulation, resulting in increasing of oxidative stress and deterioration in overripe fruit [8]. In intracellular fluid, enzymes that involved in the degradation process of ROS compounds is superoxide dismutase (SOD) enzyme and catalase. SOD plays a role in converting superoxide anion radical into hydrogen peroxide (H2O2) and molecular oxygen $\left(\mathrm{O}_{2}\right)$. Meanwhile, catalase, which is found in peroxisomes and the cytoplasm, degrading hydrogen peroxide into $\mathrm{H} 2 \mathrm{O}$ and oxygen. The final product of this reaction were two harmful species, superoxyde and hydrogen peroxide converted into $\mathrm{H}_{2} \mathrm{O}$ [9]. Another study conducted by $\mathrm{Li}$ who implied that guava has a protective effect in inflammation and oxidative stress in streptozocin-induced diabetes mice which is indicated by improvements in blood glucose levels of insulin resistance, creatinine, blood urea nitrogen, triglycerides, nonesterified fatty acids, cholesterol, c-reactive protein, TNF- $\alpha$, and IL-10 [10]. SOD enzymes itself are highly compartmentalized. Nutrition plays a key role in maintaining the body's enzyme defences against free radicals. Some minerals such as $\mathrm{Mn}, \mathrm{Cu}, \mathrm{Zn}$ and $\mathrm{Se}$ are involved in the catalytic activity of these antioxidant enzymes and are needed to control free radicals that form at an early stage [8]. Manganese containing SOD (MnSOD) is localized in the mitochondria; copper and zinc containing SOD (CuZnSOD) is located in the cytoplasm and the nucleus; and extracellular SOD (ECSOD) is expressed extracellular in some tissues [9]. Mondal found that except superoxide dismutase, the activity of all other antioxidant enzymes in the fruits such as catalase, peroxidase, ascorbate peroxidase and glutathione reductase increased until the colour change stage and then decreased afterwards [8].

Superoxide dismutase activity increased in a mature stage but then followed by a decrease its activity soon after. The content of ascorbic acid and glutathione (total, oxidized and reduced) is found to be maximum when the fruit is fully mature. It was concluded that ripening of guava fruit was accompanied by a progressive increasing in oxidative / peroxidative stress which induces an antioxidant system but not until the next maturation stage. Excessive accumulation of ROS compounds can occur due to dysfunction of the ROS scavenging system in the later stages of fruit ripening. It seems responsible for the loss of tissue structure as observed in ripe and over-ripe fruit [8]. 


\section{CONCLUSION}

The results showed a better free radical scavenging activity in group which treated by medium ripe guava fruit statistically compared with control. Consumption one piece of red guava a day regularly may enhance antioxidant activity, especially due to catalase enzyme activity. The use of quercetin itself as antioxidant can be better in extract form than its use as a single compound. These result highlight that red guava fruit could be considered like a dietary supplement rich of flavonoid with the potential to be used as functional feed.

\section{ACKNOWLEDGMENT}

The author thanks, LPDP (Indonesia Endowment Fund for Education) for funding the research.

\section{REFERENCES}

[1] A.M. Pisoschi and A. Pop, "The role of antioxidants in the chemistry of oxidative stress: A review," Eur J Med Chem, vol. 97, pp. 55-74, 2015.

[2] T. Wresdiyati, M. Astawan and L.Y. Hastanti, "Profil Imunohistokimia Superoksida Dismutase (SOD) pada Jaringan Hati Tikus dengan Kondisi Hiperkolesterolemia,” Hayati J Biosci, vol. 13, no. (3), pp. 85-9, 2006.
[3] A.G. Vasconcelos, G.N. Amorim A das, R.C. dos Santos, J.M.T. Souza JMT, L.K.M. de Souza, S.L. Araújo T de, et al. "Lycopene rich extract from red guava (Psidium guajava L.) displays anti-inflammatory and antioxidant profile by reducing suggestive hallmarks of acute inflammatory response in mice," Food Res Int, vol. 99, pp. 959-68, 2017.

[4] E.Y. Sukandar, R.I.K. Adnyana and R.S. Nurfitria, "Antioxidant potential of garlic and turmeric mixture-A traditional Indonesian formulation,” Indian J Tradit Knowl., vol. 14, no. (4), pp.632-6, 2015.

[5] G. D'Andrea, "Quercetin: A flavonol with multifaceted therapeutic applications?" Fitoterapia, vol. 106, pp. 256-71, 2015.

[6] P. Mittal and V. Gupta, "Phytochemistry and pharmacological activities of psidium guajava: a review," J Phar Sci Res, vol. 1, no. (9), pp. 9-19.

[7] S.M. Barbalho, F.M.V. Farinazzi-machado, R.D.A. Goulart, A. Cláudia S. Brunnati and A.M. Machado, "Psidium Guajava (Guava): A Plant of Multipurpose Medicinal Applications," Med Aromat Plants, vol. 01, no. (04), pp. 1-6, 2012

[8] K. Mondal, S.P. Malhotra, V. Jain and R. Singh, "Oxidative stress and antioxidant systems in Guava (Psidium guajava L.) fruits during ripening," Physiol Mol Biol Plants, vol. 15, no. (4), pp. 327-34, 2009.

[9] C.J. Weydert and J.J. Cullen, "Measurement of superoxide dismutase, catalase and glutathione peroxidase in cultured cells and tissue," Nat Protoc., vol. 5, no. (1), pp. 51-66, 2010.

[10] P.-Y. Li, C.-C. Hsu, M.-C. Yin, Y.-H. Kuo, F.-Y. Tang, C.-Y. Chao, "Protective Effects of Red Guava on Inflammation and Oxidative Stress in Streptozotocin-Induced Diabetic Mice," Molecules, vol. 20, no. (12), pp. 22341-50, 2015 